\title{
Cultural Tourism Guidelines In Klonghae Floating Market, Thailand
}

Narawadee Buakwan, Prince of Songkla University, Thailand

Parichart Visuthisamajarn, Prince of Songkla University, Thailand

Amporn Viriyakoson, Prince of Songkla University, Thailand

\begin{abstract}
This study was to provide guidelines for managing cultural tourism in the Klonghae Floating Market, Klonghae sub-district, Hatyai district, Songkhla province, Thailand. Both qualitative and quantitative methods were used to collect data. It was discovered that the floating market, which opened in August 2008, was managed by the local government to support environmental conservation and economic development in the community. Our guidelines emphasized the need to connect the floating market with other tourist attractions within the Klonghae municipal area to update information provided to potential tourists. It was discovered that visitors want more information about temples and livelihoods.
\end{abstract}

Keywords: Klonghae Floating Market; Cultural Tourism

\section{INTRODUCTION}

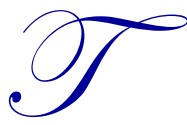

he global market is changing tourists' consumption behaviors and has broadly impacted two types of tourism. In the past, tourists visited natural attractions, such as sea sides, waterfalls, mountains, and caves, in order to observe natural phenomena, and they also visited manmade sites, such as Buddhist temples, castles, palaces, and old buildings to appreciate their historic and aesthetic value. As people become wealthier and transportation improves, more tourists come to the sites visited by others in the past (Galvani, 2005). Today there are several types of alternative tourism - ecotourism, community-based, health, gastronomic, and rural that attract modern tourists (D'mello, 2008). Cultural tourism is also an attraction for them (Ratanakomut, 2006). Site managers need information about attracting tourists and sharing the benefits that tourists bring to the community.

Cultural tourism sites attract visitors who want to learn about the culture and livelihoods of people in a foreign place and environmental conservation (OECD, 2009). There are a variety of activities related to cultural tourism as the floating market in Klonghae, Thailand, draws the attention of tourists. Many people from nearby local communities take part in floating market which is a space where products are exchanged between sellers and consumers. For a long time, this type of market has made it possible for villagers to communicate and earn a good living in Thailand. Nevertheless, the floating market is a new phenomenon in the southern part of Thailand, and this prompted the research question, "What is the best way to manage a floating market and promote cultural tourism in the southern region?"

\section{OBJECTIVE}

The aim of this study was how to manage the Klonghae floating market, Klonghae sub-district, Hatyai district, Songkhla province, Thailand.

\section{METHODOLOGY}

This research focused on the topic of management techniques to attract tourists to the Klonghae floating market. Both qualitative and quantitative methods, as well as observation and questionnaires, were used for collecting data through semi-structured interviews (Simaraks \& Supatera, 1987). 


\section{Data Collection}

Primary data were collected in March 2011 using the following steps:

1. In-depth interviews were conducted with dealers in the floating market (10 persons), tour operators (3 persons), and government officials (5 persons), a chairman at the nearby temple ( 3 persons), leaders of the community ( 3 persons), and tourists (10 persons).

2. $\quad$ Four hundred completed questionnaires were collected from visitors to the floating market.

3. A field survey was performing to check the structure of community and floating markets.

\section{Study Site}

The Klonghae floating market is located in the Klonghae sub-district, Hat Yai district, Songkhla province, about $10 \mathrm{~km}$ from the Hat Yai municipal area (Figure 1).

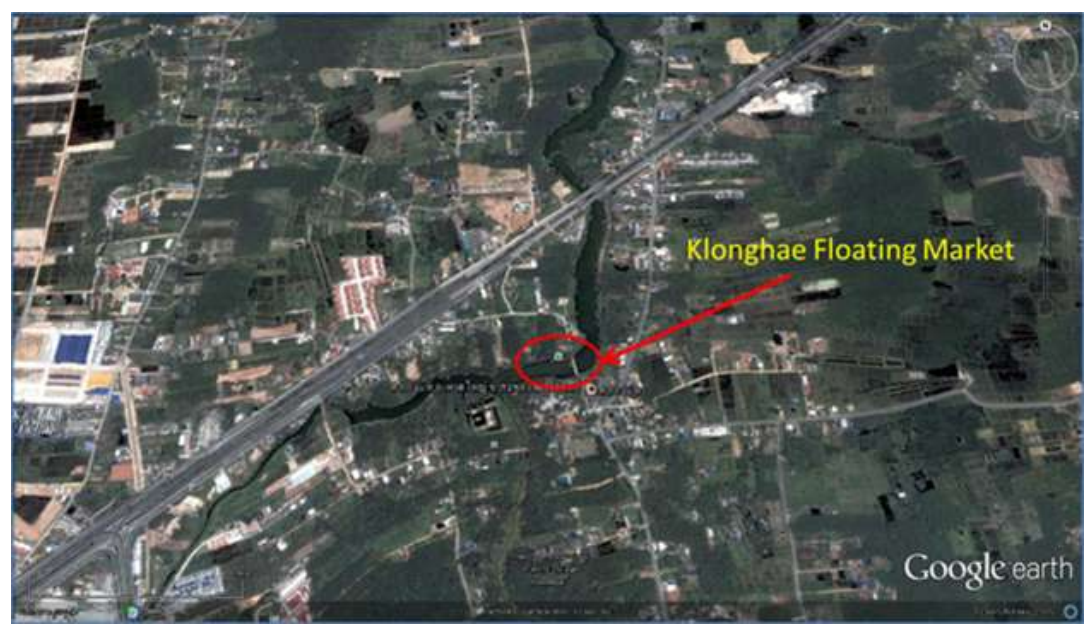

Figure 1: The location Of The Klonghae Floating Market

Source: Google Earth

\section{Data Analysis}

The collected data were analyzed and reviewed after the completion of field work. Incomplete or conflicting data were filled in or clarified during more interviews, so this research used a content analysis technique for analyzing data as well as a triangulation technique.

\section{RESULTS}

\section{Policies Related To Klonghae Floating Market Management}

Local politicians developed policies regarding the Khlonghae floating market in order to develop the environment and financial well-being in the community. The floating market first opened during the Songkran festival (water festival) in April 2008, feedback was gathered from tourists and operators, and the floating market was officially opened in August 2008. The local politicians developed two policies for managing the floating market.

\section{Environmental Conservation}

First, they advocated canal improvements, such as a water treatment system or dam construction, in the upper canal and they recommended planting VetiveriaZizanioides Nash on the embankment. Second, they recommended developing the landscape in the community to support tourism. Third, since most of the products sold 
in the market are foods, they recommended that natural raw materials, like bamboo and banana leaves, should be used as drinking vessels and to wrap food.

\section{Economic Development}

The officials advised local administrators to give first priority to local people in the community to open shops in the floating market. Second, they set up rules concerning the prices of products, ordering that food prices should not be more than 0.60 USD each (1 USD = approximately 33 baths). Third, they set up connections with tour operators with programs to visit the floating market.

\section{Types Of Tourism In Klonghae Floating Market}

There are two types of tourists visiting Klonghae floating market: 1) Domestic - 60\% of those in this category of our sample lived in Songkhla province and $40 \%$ lived outside the province and 2) International - almost all of them are from Malaysia, Singapore, and other places $(60 \%, 30 \%$, and $10 \%$, respectively), many of whom contact a tour group company.

\section{Cultural Resources Near Klonghae Floating Market}

Area and Space

Many structures nearby are related to the Buddhist religion and beliefs, such as the Klonghae, Amphawan, Narangnok, and Khutoa temples as well as the Charemrat museum.

History

There are many popular legends, including one about Konokkhum, the black- tongued monk, that relate to the livelihoods and natural resources of the community around Klonghae floating market.

Festivals

The Songkhan festival (water festival) includes Manora (local dance), boat racing, etc.

Livelihood

Tourists are interested in activities, such as Manora, local music, Talung theater, etc. and architecture, such as the structure of temples and pictures inside the Khutoa temples.

\section{Cultural Tourism Aims Of Visitors To Klonghae Floating Market}

Visitors' Goals

People we interviewed said that they came to Klonghae floating marker in order to taste new foods (21.5\%), relax (16.4\%), take photos (15.2), sightsee (10.9), study the culture, and livelihood of local people (9\%), and for other reasons, such as buy products and do research $(27 \%)$.

\section{Guidelines For Cultural Tourism Management}

Coordination of Visits to Tourist Sites in the Klonghae Floating Market

The Klonghae municipal area has many interesting places people can visit before going to the floating market, such as the Khukaow temple, Lampho beach, birdcage village, and the central mosque. After enjoying activities at the floating market, they can practice Manora in the Klonghae temple, which will help them understand the local culture of those living in the Klonghae community. 


\section{Information}

The local government established an information center to support tourism and it set up a website (http://www.klonghea.go.th), publishes a newsletter, and feeds stories to local news outlets to provide tourists with information about attractions in the community. However, those who have studied the cultural tourism concept understand that visitors appreciate information about the history of places that they visit. Tour guides should work with local government officials to plan methods of transmitting such information to visitors.

\section{Attractions}

The floating market is currently open only during weekends (Friday, Saturday, and Sunday), allowing tourists very little opportunity to visit the community. If possible, it should also be open on any festival day.

\section{Promoting Tourism In The Klonghae Municipal Area}

Most tourists are aware of the floating market. However, there are other cultural tourism sites that few know about, such as temples and the lives of fishermen and agricultural workers in the community.

\section{CONCLUSIONS}

The study of cultural tourism guidelines in the Klonghae floating market aimed to provide procedures for managing its tourism. The local government created the Klonghae market in August of 2008 to increase the income of villagers and promote environmental conservation. However, the study found that the market had the potential to develop cultural tourism, so it outlined guidelines to develop this potential resource. The four components of these guidelines were:

1. There should be coordination between tour operators and the local government to set the tour route and distribute visitors to other places.

2. The local government should establish an information center to support tourism and set up a website, and tour guides should work with the local government officials to plan methods of transporting.

3. The local government must attract activity in the market.

4. The local government must promote the relationship between the floating market and the livelihood of the villagers in the Klonghae community.

\section{ACKNOWLEDGMENTS}

This research was financially supported by Strategic Scholarships Fellowships Frontier Research Networks (Specific for Southern region) under the Office of the Higher Education Commission (OHEC).

\section{AUTHOR INFORMATION}

Miss NarawadeeBuakwan is a Ph.D. candidate, Faculty of Environmental Management, Prince of Songkla University, Hatyai, Songkhla, Thailand. She is a tourism management specialist. E-mail: bnarawadee@gmail.com Corresponding author

Dr. ParichartVisuthismajarn is an assistant professor at the Faculty of Environmental Management, Prince of Songkla University, Hatyai, Songkhla, Thailand. She is a risk management and ecotourism specialist. E-mail: parichart.v@psu.ac.th

Mrs. Amporn Viriyakoson is an association professor at the Faculty of Management Science, Prince of Songkla University, Hatyai, Songkhla, Thailand. She is a management and tourism specialist. E-mail: amporn.v@psu.ac.th 


\section{REFERENCES}

1. Galvani, A. 2005.The Sustainable Tourism for the Europe of the Third Millennium. Retrieved from, http://amsacta.cib.unibo.it/2569/1/GalvaniTourism.pdf

2. D'mello, C. 2008. Transforming re-forming tourism: Perspectives on justice and humanity in tourism.Chiang mai, Thailand.

3. Ratanakomut, S. 2006. Community Awareness and Cultural Tourism Sustainability. APEC Study center Consortium Conference Ho Chi Minh City Viet Nam, 23-24 May 2006.

4. Simaraks, S. and Supatera, S. 1987.[editor] Rapid rural appraisal manual. Farming Systems Project. KhonKaen University, Thailand

5. OECD. 2009. Chapter 7: The Vorarlberg Province, Austria, The Impact of Culture on Tourism, OECD, Paris, pp. 97-113. Retrieved from, http://www.oecd.org/newsroom/43125523.pdf 
NOTES 